\section{Еліна ШИШКІНА}

\section{Повага до людської гідності в контексті війни: компенсація за завдану шкоду}

\begin{abstract}
Стаття присвячена питанню поваги до людської гідності в контексті збройного конфлікту на прикладі права внутрішньо переміщених осіб на реституцію і компенсацію за втрачене, пошкоджене або зруйноване майно в результаті війни. Окрім того, в статті піднімаються питання щодо суті людської гідності, іії поваги і захисту в період збройних конфліктів, а також iï зв'язку із зазначеним правом. Зроблений висновок, що реалізація права на компенсацію та кореспондуючий йому обов' язок держав створити відповідні національні законодавчі механізми є невід' ємними елементами відновлення справедливості та ущемленої людської гідності осіб, які страждають від наслідків війни.
\end{abstract}

Ключові слова: людська гідність, внутрішньо переміщені особи, реституція, компенсація.

The article talks about the respect for human dignity in the context of armed conflict by providing an example of the right of internally displaced persons to restitution and compensation for lost, damaged or destroyed property because of war. In addition, the article raises questions on the meaning of human dignity, its respect and protection during the armed conflicts, as well as its connection with the aforementioned right. As concluded, the implementation of the right to compensation and the corresponding obligation of States to create appropriate national legal mechanisms are key elements of restoring justice and human dignity of those who suffer from the consequences of war.

Keywords: human dignity, internally displaced persons, restitution, compensation.

\title{
Вступ
}

«Усі люди народжуються вільними і рівними у своїй гідності та правах» - саме так зазначає ст. 1 Загальної декларації з прав людини 1948 р. [1]. Однак якщо свобода та рівність у правах все ж є більш зрозумілими категоріями, то спроби осягнути суть людської гідності породжують безліч питань. Як часто ми замислюємося про те, що є нашою гідністю? Власне сприйняття цього явища у звичайному житті пов' язане переважно із вимогою поважати себе як людську істоту, ставитися як до рівного собі, не порушувати людських прав. У стосунках із державними структурами та чиновниками діє також вимога щодо гідного ставлення до громадян. У повсякденному житті повага до людської гідності асоціюється із дотриманням прав людини та можливістю їхньої реалізації, наприклад, під час кримінального переслідування, коли конституційно встановлена абсолютна заборона катувати чи іншим подібним чином отримувати покази про здійснення злочину, або коли для держави визначені межі втручання у приватне життя людини, вихід за які вже розглядається як порушення права на приватність. Можна назвати безліч таких випадків зі звичайного життя і всі вони так чи інакше стосуватимуться тематики поваги до людської гідності, а закони, що діють у мирний час, створюють різноманітні механізми для іï захисту. Проте під час війни питання щодо поваги до гідності людини, як такої, яка безпосередньо страждає від ії наслідків, підносить значимість цієї цінності на новий рівень. Незважаючи на те, що війна як результат боротьби за сфери впливу і влади, а також реалізації нездорових амбіцій правлячих верхівок держав, різко знецінює життя людини та перетворює іiі у звичайнісінький об'єкт, цей рукотворний катаклізм тим не менш ставить руба питання - чи є місце для поваги до людської гідності під час війни та як можливо захистити тих, хто від неї постраждав? Метою цієї статті є спроба розглянути чи поважається людська гідність тих осіб, 
які не є комбатантами або особами, які знаходяться в окупації, проте залишаються на підконтрольних уряду територіях, щоденно потерпаючи при цьому від наслідків війни.

В українській науці тематика людської гідності лише в останні п'ятнадцять років стала предметом грунтовних наукових досліджень у сфері права. Щоправда, у багатьох наукових роботах стосовно людської гідності, вона є об'єктом аналізу переважно через призму кримінально-правового аспекту (гідність є об'єктом кримінально-караного посягання) або у цивільно-правовому контексті - у прив'язці до честі і ділової репутації, проте не в сфері конституційного права. Більше того, тема поваги і захисту людської гідності в контексті збройного конфлікту поступово стає у центрі наукових пошуків лише з початком збройної агресії Російської Федерації проти України. Тим не менш, серед українських науковців, які здійснюють саме філософсько-правові пошуки щодо суті цього явища першопроходьцями у цій царині можна вважати В. Буткевича, О. Грищук, С. Добрянського, П. Рабиновича, С. Рабиновича.

\section{І. Людська гідність: основні філософсько-правові засади}

Перш ніж перейти до основного питання цієї статті, варто зрозуміти чим власне є людська гідність. Впродовж тисяч років людство здійснює різноманітні філософські пошуки заради пізнання людської гідності та намагається знайти остаточні відповіді. 3 одного боку ці пошуки відбуваються у площині філософії, релігії, психології, права тощо. 3 іншого - однозначної або чітко визначеної відповіді немає і не може бути, оскільки стрімкий розвиток буття людства та його уявлень про власну природу провокує появу нових питань у світлі нових аспектів. Тим не менш основоположником сучасного розуміння людської гідності як «цінності в собі» є німецький філософ І. Кант, який розглядав гідність як загальнолюдську цінність саме тому, що лише людина має здатність бути моральною істотою, тобто діяти на підставі чистого обов'язку і визнавати когось іншого здатним бути моральним, а моральне поняття пов'язував 3 притаманною для індивіда особистою і громадянською свободою. Доказом самоцінності гідності є те, що вона, на відміну від ціни, не має еквівалента [2]. За визначенням К. Цомплака людська гідність є проявом людської природи, вона є єдиносущною 3 людиною [3, с. 17]. Такий об'єктивістський підхід виражає людську гідність як апріорне явище, тобто те, що є безцінним, таким, що надане людині в силу їі природи. Саме такий погляд на людську гідність визначає ііі як абсолютну цінність людини, яка не потребує жодних доказів чи доведення свого існування. Виходячи 3 цього, гідність є родовим поняттям, ознакою приналежності до людського роду. Звідси випливає, що жодним чином вона не може бути ущемлена, порушена чи знецінена, оскільки в такому випадку ставиться під сумнів «людськість» людини. Враховуючи це, вказана цінність людини, тобто та, якою наділена кожна особа без винятку, незалежно від її індивідуальних особливостей чи соціального статусу, розуміється як універсальна властивість окремої людини та людства загалом. Звідси - людська гідність є суттю людства, на відміну від категорії свободи, яка є суттю прав людини [4, с. 29]. Цей же підхід, за яким людська гідність введена в абсолютну величину, а також визнана джерелом природних прав людини за преамбулою Міжнародного пакту про громадянські та політичні права 1966 р. [5], покладений в основу сучасної системи захисту прав людини як у мирний час, так і під час військових дій. 3 іншого боку, цей феномен постає як самоцінність людини, іiї повага до себе, тобто йдеться про гідність конкретної людської особистості у її власних очах. За таким підходом, який ще часом називають суб'єктивістським, гідність людини визначають як усвідомлення людиною своєї значущості і суспільної ваги [6, с. 594]. Цілком можливо, що саме 3 такої позиції людську гідність розглядав відомий американський вчений-правник Рональд Дворкін, який, як зазначає О. Грищук, вважав, що почуття власної гідності є важливим первинним благом i включає два аспекти: відчуття людиною власної значимості, її тверде переконання в тому, що иї концепція власного блага, життєвого плану заслуговує реалізації; самоповага, що включає впевненість у власних силах [7, с. 28].

Виходячи із розгляду цієї категорії за вказаними двома підходами, гідність людини є поняттям моральної свідомості, що виражає уявлення про цінність кожної людини як моральної особистості, як людської істоти, а також являє собою окреме моральне ставлення людини як до себе самої, так і з боку суспільства, в якому визнається цінність певної особистості [8, с. 180]. Констатація того, що гідність людини є більш основоположним поняттям, ніж будь-яке специфічне право людини, дозволяє стверджувати, що це явище є джерелом усіх моральних принципів, а не моральним принципом як таким [9, с. 191]. 3 позиції погляду на гідність людини як морально-етичну і філософську категорії, вказана цінність є об'єктивно недоторканою, однак насправді вкрай уразливою і може бути принижена або спотворена, особливо внаслідок дій як державних інституцій, так і окремих представників держави. 3 огляду на це, гідність як властивість людини в силу її по- 
ходження, потребує в першу чергу правового забезпечення та охорони, тобто має бути об'єктом правового захисту.

Разом $з$ тим людська гідність є не лише висхідним моральним принципом, джерелом прав людини, цінністю у праві. Фактично, вона є фундаментом демократичного правопорядку, а повага до неї і високий рівень ії захисту є чинником, завдяки якому визначається правність держави. Сучасний німецький філософ права Юрген Хабермас зазначає: «Людська гідність відіграє роль сейсмографра, який показує з чого утворюється демократичний правопорядок, а саме ті права, якими члени політичної спільноти наділяють самі себе, якщу вони поважають одне одного як вільних та рівних осіб. Гарантія ијх прав людини спонукає осіб, як суб'єктів рівних прав, вимагати поваги до їхньої ююдської гідності ... ^юдська гідність створюе «портал», через який рівноправна (егалітарна) та універсалістська сутність моральності імпортована у право. Ідея людської гідності є концептуальною суттю, яка поєднує моральність рівної поваги до будь-кого з позитивним правом і демократичною правотворчістю у такий спосіб, щуо їхня взаємодія може дати початок політичному порядку, який базується на правах людини» [10, с. 469].

Зважаючи на наведене, людська гідність є явищем, яке пронизує абсолютно всі сфери буття людини, цінністю, яка сприймається як аксіома, головною ідеєю, яка є «nоyau dur» (термін, що часто зустрічається у франкомовній правничій літературі - прим. автора), тобто основоположною засадою ліберальної концепції прав людини.

Разом $з$ тим якою б глибинною за своєю суттю не була людська гідність і яким би фундаментальним не було іï призначення, тим не менш, як вже було сказано, ця властивість людини є надзвичайно тендітною і вразливою для різноманітних посягань. Саме тому вона потребує захисту з боку права. Окрім того, незважаючи на свою метафізичну сутність, людська гідність потребує щоденного практичного втілення. На жаль, ії пізнання відбувається переважно через ущемлення, приниження, тобто через знецінення у будь-який спосіб. Проте оскільки це явище є апріорним, то гносеологічний пошук ії суті має відбуватися не лише через заперечення, а перш за все через повагу до неї. Таким чином, для того щоб зрозуміти що ж являє собою людська гідність, недостатньо розглядати ії як об'єкт посягань, варто також ставити питання за яких умов вона не буде знецінена. Будучи ірраціональною, гідність не піддається логічному осмисленню, визначенню чи встановленню обмежень, так як не може існувати кордонів для людської природи. Саме з цієї причини питання поваги, її збереження та захисту має лягати в основу будь-якої правової держави і знаходити відображення у здійсненні нею своїх функцій. Гідність об'єктивно притаманна кожній людині, але відчуття людиною себе як цінності (почуття власної гідності) з'являється лише за певних умов, створення яких є основним обов' язком держави щодо людини.

\section{II. Людська гідність в контексті збройного конфлікту}

Із початком будь-якого збройного конфлікту завжди постає питання - чи застосовуються 3 метою захисту прав людини лише норми міжнародного гуманітарного права як права війни чи паралельно із ними також можуть бути застосовані норми міжнародного права з прав людини як права мирного часу. Безумовно, що під час війни певні обмеження прав людини є правомірними і допустимими, навіть право на життя не може бути гарантоване державою, що обумовлено самою природою війни, результатом якої є смерть великої кількості людей. Окрім того, норми міжнародного гуманітарного права вступають у дію автоматично як тільки починаються воєнні дії. 3 одного боку це може вказувати на певний пріоритет положень міжнародно-правових документів щодо збройних конфліктів, 3 іншого - норми міжнародного права $з$ прав людини так само застосовуються, особливо на тій території держави, де не ведуться бойові дії. Незважаючи на те, що співвідношення міжнародного гуманітарного права і загального захисту прав людини в міжнародних збройних конфліктах є проблематичним, тим не менш визнаним є те, що встановлені права людини у будь-якому разі не підлягають автоматичному позбавленню чинності через початок такого конфлікту [11, с. 433]. Відповідно до ст. 2 Женевської конвенції про захист цивільного населення під час війни від 12.08.1949 р., на додаток до положень, що втілюються у мирний час, її положення застосовуються до всіх випадків оголошеної війни чи будь-якого іншого збройного конфлікту, що може виникнути між двома чи більше Високими Договірними Сторонами, навіть якщо одна 3 них не визнає стану війни [12]. Виходячи 3 цього, обов' язки держав щодо гарантування та захисту певних прав людини, які вони взяли на себе у мирний час, залишаються для них чинними і під час війни.

Як же у цьому випадку бути із захистом людської гідності? Міжнародно-правові документи у сфері гуманітарного права містять чимало таких положень. У цьому міжнародне гуманітарне право та міжнародне право із захисту прав людини мають однаковий підхід - людська гідність є абсолютною цінністю і не може бути знецінена навіть під час збройного конфлікту, а до всіх його сторін 
висувається вимога забезпечити повагу до вказаної цінності людини. Прикладом можуть слугувати положення Женевських конвенцій 1949 р. та додаткових Протоколів до них 1977 р. щодо захисту військовополонених, поранених та осіб, що залишилися в окупації від катувань, нелюдського поводження, завдання каліцтва, наруги над людською гідністю, медичних дослідів тощо. У цьому контексті також варто навести ст. 15 Конвенції про захист прав людини та основоположних свобод, яка дозволяє державам-учасницям відступати від ії положень у разі загрози життю нації [13, с. 52]1 . Проте такий відступ не розповсюджується на деякі статті документу, зокрема на їі ст. 3, яка встановлює заборону катувань, нелюдського і такого, що принижує гідність, поводження або покарання. Положення цієї статті вже давно має значно ширшу інтерпретацію і стосується в цілому захисту права людини на повагу до своєї гідності. Таким чином, навіть під час збройного конфлікту, держава зобов' язана докладати всіх зусиль, створювати всі необхідні умови, за яких людська гідність як абсолютна цінність людини буде захищена. У цьому випадку йдеться не лише про вимогу до держави забезпечити безпеку осіб, що проживають на ії території, але й створити механізми та інструменти, завдяки яким ті особи, що найбільше потерпають від наслідків конфлікту, не відчували б себе покинутими, непотрібними і в результаті негідними, тобто не вартими уваги і поваги до себе. Виходячи 3 наведеного, рівень захисту людської гідності має бути значно вищим у таких специфічних умовах як збройний конфлікт, і відповідний обов'язок держави ніяким чином не може бути скасований у зв'язку із цими обставинами.

\section{III. Повага до людської гідності в контексті війни: компенсація за завдану шкоду}

В контексті збройного конфлікту постає також питання щодо захисту гідності тих осіб, які, хоча і не $є$ комбатантами чи населенням, яке залишилося на окупованих територіях, проте зазнали страждань, а їхні долі були понівечені в результаті війни. Йдеться про одну з найбільш вразливих категорій осіб - тих, що постраждали від конфлікту (англ. - conflict affected people, фp. - personnes affectées par le conflit). Ця категорія включає в себе як внутрішньо переміщених осіб (англ. - internally displaced persons, фp. - personnes déplacées à l'intérieur) так і осіб, які проживають у прифронтовій зоні. Із початком збройної агресії Російської Федерації у 2014 році Україна зазнала значного переміщення людей всередині країни, результатом чого стала наявність більше 1,5 млн. переселенців ${ }^{2}$. Згідно із Керівними принципами ООН з питань внутрішнього переміщення, такими особами вважаються особи або групи осіб, які були змушені покинути свої будинки або місця постійного проживання, зокрема в результаті або з метою уникнення наслідків збройного конфлікту, ситуації загального насильства, порушень прав людини, стихійних або антропогенних лих і які не перетнули міжнародно визнаний державний кордон [14]. Для цілей цієї статті розглянемо детальніше питання щодо поваги до людської гідності внутрішньо переміщених осіб на прикладі компенсації за пошкоджене/зруйноване майно.

Загалом, варто зазначити, що міжнародні документи у вказаній сфері є актами «м’якого права», які, тим не менш, встановлюють обов'язки держав-членів міжнародних організацій (ООН, Рада Свропи тощо) із захисту прав внутрішньо переміщених осіб. Вже згадані Керівні принципи ООН містять перелік таких прав та кореспондуючих ним обов'язків держав, серед яких необхідно вказати на заборону дискримінації, катувань, жорстокого і нелюдського поводження, обов'язок поважати приватне і сімейне життя переселенців, а також обов'язок надати їм компенсацію чи справедливе відшкодування в іншій формі майна та власності, яке було залишене чи вилучене в результаті збройного конфлікту. Щодо останнього, то відповідні обов' язки держав є значно більш деталізовані в іншому документі, а саме - у Заключній доповіді спеціального доповідача Комісії $з$ прав людини Економічної і соціальної Ради ООН (ЕКОСОР) «Принципи з питань реституизї житла та майна біжениів та переміщених осіб» (Принципи Пінейру) [15]. Відповідно до пп. 2.1 і 2.2 документу переміщені особи мають право на повернення їм будь-якого житла, землі та/або майна, якого вони були довільно або незаконно позбавлені, або на отримання компенсації за будь-яке житло, землю та/або майно, які не можуть бути повернуті, відповідно до фактів, встановлених незалежним, неупередженим судом. При цьому держави повинні наочно приділяти першочергову увагу праву на реституцію як

\footnotetext{
${ }^{1}$ Відповідно до ст. 15 Конвенції Україна заявила про свій відступ від ії положень у зв'язку із збройною агресією Російської Федерації. Див. постанову Верховної Ради України № 462-VIII від 21.05.2015 «Про Заяву Верховної Ради України «Про відступ України від окремих зобов'язань, визначених Міжнародним пактом про громадянські і політичні права та Конвенцією про захист прав людини і основоположних свобод» // Відомості Верховної Ради України, 2015, № 29, Ст. 267.

2 За даними Міністерства соціальної політики України станом на 10.12 .2018 р. на обліку як переселенці перебуває 1513574 особи. - Електронний ресурс. - https://www.msp.gov.ua/news/16418.html - [Доступ: 14 грудня 2018 p.]
} 
кращого способу правового захисту в разі переміщення і як одному з ключових елементів відновлення справедливості. Зазначене право, невід'ємним елементом якого є право на компенсацію, існує окремо і жодним чином не применшується поверненням або ж неповерненням біженців і переміщених осіб, які можуть претендувати на реституцію житла, землі і майна. У Принципах Пінейру так само встановлені обов' язки держав ухвалювати відповідні законодавчі акти у вказаній сфері 3 метою захисту права внутрішньо переміщених осіб на компенсацію. Так, згідно із п. 18.1 держави забезпечують, щоб вказане право цих осіб визнавалося як істотно важливий елемент принципу верховенства права, що включає в себе використання всіх необхідних законодавчих засобів, зокрема прийняття, зміну, реформування або скасування відповідних законів, правил та/або практики. Окрім того, такі правові положення мають бути чіткими, узгодженими i, в разі потреби, об'єднаними в єдиному законі. Відповідно до п. 18.3 Принципів держави забезпечують, щоб національне законодавство 3 питань реституції житла, землі і майна було внутрішньо узгодженим і сумісним з існуючими договорами, такими, як мирні угоди і угоди про добровільну репатріацію, якщо ці угоди відповідають положенням і стандартам міжнародного права із захисту прав людини, зокрема біженців, та міжнародного гуманітарного права. Окрім того, п. 19.1 цього документу встановлює обов' язки держав не допускати прийняття дискримінаційних чи несправедливих законів, які наносять шкоду процесу реституції або позбавляють чи обмежують відповідні права.

Незважаючи на те, що Керівні принципи ООН 3 питань внутрішнього переміщення та Принципи Пінейру є актами «м'якого права», тобто не мають обов'язкової юридичної сили, їхні положення тим не менш встановлюють певні універсальні стандарти щодо захисту цієї вразливої категорії осіб, яких держави-члени ООН повинні дотримуватися при здійсненні своєї внутрішньої політики в період збройних конфліктів та після них. Окрім того, оскільки обов'язок держав забезпечити реалізацію права постраждалих осіб на реституцію і компенсацію шкоди, завданої внаслідок збройного конфлікту може бути виведений із обов'язку поважати та захищати їхню людську гідність та принципу верховенства права, то положення цих актів все ж є приховано обов'язковими до виконання.

Подібний підхід до вказаних обов' язків держав застосовують також інституції Ради Свропи, зокрема Парламентська асамблея Ради Свропи (далі - ПАРЕ). Окремі політико-правові акти цієї структури стосуються питання щодо захисту прав внутрішньо переміщених осіб в Європі та гідного до них ставлення. Так, в контексті пошуку довготривалих сталих рішень щодо зменшення негативних наслідків від внутрішнього переміщення, ПАРС у своїй Рекомендації 1877 (2009) «3абуті ^юди Європи: захист прав ююдини осіб, які переміщені на тривалий час» [16] закликає держави відновлювати права на майно та/або надавати швидку, ефективну й справедливу компенсацію у випадках, коли реституція неможлива (п. 15.3.6.). Відповідно до Резолюції ПАРС 1708 (2010) «Вирішення майнових питань біженців і внутрішньо перемішених осіб» [17] державам-членам бажано гарантувати вчасне та ефективне відшкодування втраченого доступу та прав на житло, землю і майно, не очікуючи результатів переговорів; переконатися, що таке відшкодування має форму реституції шляхом підтвердження юридичних прав біженців і переміщених осіб на їхнє майно й відновлення їхнього безпечного фізичного доступу до такого майна та володіння ним, а якщо реституція неможлива, має надаватися належна компенсація, яка відбувається через підтвердження попередніх юридичних прав на майно та надання коштів і речей, які мають відповідне співвідношення до їхньої ринкової вартості або через інші форми справедливого відшкодування. Окрім того, згідно із п. 10.8. Резолюції ефективність відшкодування через реституцію або компенсацію вартості залишеного майна має бути забезпечена шляхом встановлення компенсації моральної шкоди, пов' язаної з обставинами, через які сталося або затяглося переміщення та виселення; відшкодування шкоди, завданої внаслідок переміщення та відсутності доступу до полишеного майна, як-от втрата доходу та витрати, яких не було б, якби особи не були змушені покинути свій дім; компенсації за незаконне знищення чи пошкодження нерухомого майна чи втрати значного рухомого майна, що були спричинені діями або бездіяльністю органів влади, до юрисдикції яких належить таке майно.

Розглянуті обов' язки держав містяться не лише в актах міжнародних організацій, але також виведені у судовій практиці, зокрема в рішеннях Європейського суду з прав людини щодо застосування ст. 1 Протоколу 1 до Конвенції про захист прав людини та основоположних свобод. Постановляючи рішення у справах, в яких йшлося про необхідність компенсації внутрішньо переміщеним особам за відсутність доступу до власності, за пошкоджене або зруйноване майно внаслідок бойових дій, Суд дійшов висновку про наявність у держав-учасниць Конвенції обов'язку не лише компенсувати такі збитки, але й впроваджувати національні механізми реституції та компенсації (Loizidou v. Turkey від 18.12.1996; Сyprus v. Turkey від 10.05.2001; Doğan and Others v. Turkey від 29.06.2004; Xenides-Arestis v. Turkey від 22.12.2005). 
В контексті російсько-української війни зазначене питання також неодноразово ставало предметом обговорень в ПАРЄ і було відображене у кількох актах цієї інституції. До прикладу можна назвати п. 10 Резолюції ПАРЄ 2133 (2016) «Засоби правового захисту від порушень прав людини на українських територіях, що знаходяться поза контролем української влади» [18], в якому вказано, що у зоні конфлікту в регіоні Донбасу цивільне населення, а також велика кількість комбатантів постраждали від порушень їхніх прав, зокрема права на вільне користування майном, внаслідок воєнних злочинів та злочинів проти людяності. У зв'язку із цим згідно із п. 17.1.3. Асамблея закликає компетентні органи як в Україні, так і в Російській Федерації, компенсувати завдану жертвам шкоду у максимально можливому розмірі. Окрім того, п. 11.10 Резолюції ПАРЄ 2198 (2018) «Гуманітарні наслідки війни $b$ Україні» [19] містить також заклик до українського уряду розробити національний механізм компенсації жертвам серед цивільного населення, які постраждали під час війни. Оскільки вказаний пункт не $є$ конкретизованим, то можливо припустити, що йдеться не лише про механізм компенсації за пошкоджене/зруйноване майно, але й за заподіяну моральну шкоду внаслідок збройного конфлікту.

Загалом питання щодо забезпечення права на реституцію і компенсацію внаслідок російсько-українського збройного конфлікту є чутливим не лише для вимушених переселенців, але й для осіб, які живуть у прифронтовій зоні і потерпають від пошкоджень чи руйнувань своїх помешкань внаслідок щоденних обстрілів із різних видів зброї, зокрема артилерійських і танкових. Починаючи з 2014 p. в Україні було пошкоджено чи зруйновано близько 40 тис. будинків [20, с. 33]. Незважаючи на це, за майже п'ять років з початку збройного конфлікту досі не прийнято спеціального законодавчого акту, яким би був запроваджений зазначений механізм. На жаль, профільний Закон України 1706-VII «Про забезпечення прав і свобод внутрішнъо переміщених осіб» від 20.10.2014 [21] не містить положень щодо права цієї категорії осіб на компенсацію. Інший законодавчий акт, який опосередковано стосується прав осіб, що постраждали від конфлікту, має інакшу територіальну спрямованість, а саме на тимчасово окуповані території Донецької та Луганської областей і не стосується питань, що пов'язані з наслідками бойових дій для цивільного населення, яке проживає на лінії зіткнення. Йдеться про Закон України 2268-VIII «Про особливості державної політики із забезпечення державного суверенітету України на тимчасово окупованих територіях у Донеиькій та Луганській областях» від 18.01.2018 р. [22]. Більше того, отримання належного відшкодування за залишене, пошкоджене або знищене в результаті конфлікту майно унеможливлене виходячи з його положень. Згідно із частиною четвертою ст. 2 Закону відповідальність за матеріальну чи нематеріальну шкоду, завдану Україні внаслідок збройної агресії Російської Федерації, покладається на державу-агресора відповідно до принципів і норм міжнародного права. Виходячи з цієї норми, по-перше, держава Україна знімає з себе будь-яку відповідальність за відшкодування шкоди, по-друге, це положення не містить жодної згадки про шкоду, завдану особам, які постраждали від конфлікту.

Окрім того, таке самоусунення Української держави від вирішення питань щодо компенсації збитків ставить під удар конституційну і суспільну цінність людини. Згідно із ст. 3 Конституції України людина, іï життя і гідність є фундаментальними суспільними цінностями, а обов'язок держави $є$ поважати та захищати їх. Як вже було зазначено вище, людська гідність знаходить своє відображення в усіх сферах буття людини, є їі абсолютною цінністю та джерелом їі прав. Компенсація шкоди жертвам збройного конфлікту є інструментом відновлення порушеного права i, відповідно, людської гідності постраждалих, оскільки вказує на те, чи здатна держава створити умови, в яких людська гідність як абсолютна цінність не буде знецінена. Нерозуміння цінності людини та їі гідності має далекосяжні негативні наслідки як для правотворення, так і правозастосування. Відсутність відповідальності держави ще під час гарячої фази конфлікту є виявом зневаги до постраждалих та може завдати їм таких страждань, які будуть прирівняні до поводження, що принижує їхню гідність. Зважаючи на викладене, український законодавець, хоча формально і не порушив зазначену конституційну норму, але тим не менш поставив під удар вказану цінність людини. Саме тому він мав би враховувати положення ст. 3 Конституції України як норми прямої дії ще на етапі розробки обох згаданих законів.

\section{Висновки}

Підсумовуючи наведене, варто зазначити, що повага до людської гідності, її збереження та захист, особливо в таких складних умовах як збройний конфлікт, є одним з найважливіших обов'язків держави. Здатність людської гідності бути концептуальною суттю людського буття є тим фактором, який визначає сутність людини, а ідея гідності інкорпорована у право, визначає наскільки правовою $є$ держава. На перший погляд може здатися, що питання виплати компенсації за втрачене, пошкоджене або знищене майно в результаті конфлікту не пов'язане безпосередньо із розумінням людської 
гідності як абсолютної цінності. Однак незважаючи на свою ефемерність та удавану складність для розуміння, людська гідність може набувати конкретного, реального виміру. Для розуміння вказаного зв'язку важливо звернути увагу на те, що право на реституцію і компенсацію визнається як спосіб відновлення справедливості стосовно певної групи осіб та як невід'ємний елемент принципу верховенства права. У тому, що стосується надання компенсації за шкоду, заподіяну в результаті збройного конфлікту, йдеться насамперед про певне матеріальне відшкодування. Однак глибинним змістом таких дій держави стосовно відповідних осіб є саме вияв поваги до них, як до постраждалих від війни. Таким чином, у цьому випадку йдеться про суб'єктивне сприйняття людської гідності як самоповаги та власної значимості конкретної людини чи групи осіб, а механізм компенсації $є$ не лише інструментом забезпечення реалізації їхнього права на гідне ставлення до себе, а також способом відновлення їхньої ущемленої війною людської гідності.

1. Загальна декларація 3 прав людини, прийнята і проголошена резолюцією 217 А (III) Генеральної Асамблеї ООН від 10 грудня 1948 року. - Електронний ресурс. - http:/ zakon.rada.gov. ua/laws/show/995_015. - [Доступ: 14 грудня 2018]

2. Kant I. The Metaphysics of Morals / Mary Gregor, trans. - Cambridge, Eng.: Cambridge University Press, 1996. - XXVI. - 241 p.

3. Цомплак К. Гідність людини: сутність, зміст і передумови існування // Публічне право. № 4 (8). - 2012. - C. 14-22.

4. Pavia M.-L. La dignité de la personne humaine. Paris, Economica, 1999. - 181 p.

5. Міжнародний пакт про громадянські та політичні права, ратифікований Указом Президії Верховної Ради Української РСР від 19.10 .1973 р. - Електронний ресурс. - http:/ /zakon.rada.gov.ua/ laws/show/995_043. - [Доступ: 14 грудня 2018]

6. Новий тлумачний словник української мови : у 4 т. / [уклад.: В. Яременко, О. Сліпушко]. К : „Аконіт”, 1998-1998. - Т. 1: А-Е. - 1998. - 910 с.

7. О. Грищук. Людська гідність - джерело прав людини // Людська гідність: що ми розуміємо під «гідністю», «людиною» та «людською гідністю»?: матеріали міжнародного науково-практичного семінару «Людська гідність у праві Німеччини, Польщі та України, за фінансової підтримки міністерства закордонних справ Федеративної республіки Німеччина; Центр німецького права Київського національного університету імені Тараса Шевченка; ГО «Українсько-німецький правознавчий діалог» (Київ, 10-11 жовтня 2016) / відпов. ред. Б. Шлоер. - Харків: В деле, 2017. - 213 с.

8. Великий тлумачний словник сучасної української мови / [уклад. і голов. ред. В. Т. Бусел]. К.; Ірпінь : ВТФ «Перун», 2004. - 1440 с.

9. Голенбах Д. Розвиток римо-католицької теорії прав людини / Д. Голенбах // Релігійна свобода і права людини: богословські аспекти : у 2 т. - Львів : Свічадо, 2000-2000. - Т. 1. - 2000. С. 141-200.

10. Habermas, Jürgen. The concept of human dignity and the realistic utopia of human rights // Metaphilosophy. July 2010, Vol. 41, Issue 4, p. 464-480.

11. Матіас Гердеген. Міжнародне право / Пер. $з$ німецької. - К.: «К.I.С.», 2011. - 516 с.

12. Конвенція про захист цивільного населення під час війни від 12.08 .1949 р., ратифікована Указом Президії Верховної Ради Української РСР від 03.07.1954 // Відомості Верховної Ради (ВВР), 1954, № 5, Ст. 114.

13. Конвенція про захист прав людини та основоположних свобод // Збірка документів Ради Європи, ратифікованих Україною [уклад.: Бюро інформації Ради Свропи в Україні]. - К. : «Фенікс», 2006. - 496 c.

14. Керівні принципи ООН з питань внутрішнього переміщення, E/CN.4/1998/53/Add.2. Електронний ресурс. - https://www.ohchr.org/Documents/Issues/IDPersons/GPUkrainian.pdf [Доступ: 14 грудня 2018 р.]

15. Заключна доповідь спеціального доповідача Паулу Сержіу Пінейру «Принципи 3 питань реституції житла та майна біженців та переміщених осіб» - Електронний ресурс. - https://www. refworld.org/cgi-bin/texis/vtx/rwmain/opendocpdf.pdf?reldoc=y\&docid=4b2a01262 - [Доступ: 14 грудня 2018 р.]

16. Recommendation 1877 (2009) Europe's forgotten people: protecting the human rights of longterm displaced persons, adopted by the Assembly on 24 June 2009. - Електронний ресурс. - http:/ / assembly. coe.int/nw/xml/XRef/Xref-DocDetails-EN.asp?fileid=17759\&lang=EN\&search=UmVjb21tZW5kYXRpb24 gMTg3NyAoMjAwOSk= - [Доступ: 14 грудня 2018] 
17. Resolution 1708 (2010) Solving property issues of refugees and internally displaced persons, adopted by the Assembly on 28 January 2010. - Електронний ресурс. - http://assembly.coe.int/nw/ xml/XRef/Xref-DocDetails-EN.asp?fileid=17814\&lang=EN\&search=UmVzb2x1dGlvbiAxNzA4ICgyMDE $\mathrm{wKQ}==$ [Доступ: 14 грудня 2018]

18. Resolution 2133 (2016)1 Legal remedies for human rights violations on the Ukrainian territories outside the control of the Ukrainian authorities, adopted by the Assembly on 12 October 2016. Електронний ресурс. - http://assembly.coe.int/nw/xml/XRef/Xref-DocDetails-EN.asp?fileid=23167\&la ng=EN\&search=UmVzb2x1dGlvbiAyMTMzICgyMDE2KQ== [Доступ: 14 грудня 2018]

19. Resolution 2198 (2018)1 Humanitarian consequences of the war in Ukraine, adopted by the Assembly on 23 January 2018. - Електронний ресурс. - http://assembly.coe.int/nw/xml/XRef/XrefDocDetails-EN.asp?fileid=24432\&lang=EN\&search=UmVzb2x1dGlvbiAyMTk4ICgyMDE4KQ== [Доступ: 14 грудня 2018]

20. Доповідь Управління Верховного комісара ООН з прав людини щодо ситуації з правами людини в Україні за період з 16 травня по 15 серпня 2018 року. - Електронний ресурс. - https://www. ohchr.org/Documents/Countries/UA/ReportUkraineMay-August2018_UKR.pdf - [Доступ: 14 грудня 2018]

21. Закон України 1706-VII «Про забезпечення прав і свобод внутрішньо переміщених осіб» від 20.10.2014 р.// Відомості Верховної Ради (ВВР), 2015, № 1, ст.1

22. Закон України 2268-VIII «Про особливості державної політики із забезпечення державного суверенітету України на тимчасово окупованих територіях у Донецькій та Луганській областях» від 18.01.2018 р. // Відомості Верховної Ради (ВВР), 2018, № 10, ст.54

\section{Summary}

The article raises a question of the respect for human dignity in the context of armed conflict by giving an example of the right of internally displaced persons to restitution and compensation for lost, damaged or destroyed property because of war. One of the main tasks is to understand the connection of human dignity and the reparation of damages caused by war. For this purpose, it is necessary at first to examine this phenomenon from the philosophical and legal point of view. On the one hand, human dignity is priceless, one that provided a person because of human nature. This view defines it as the absolute value of a human being that does not require any evidence or proof of its existence. On the other hand, international legal documents recognize human dignity as a source of natural human rights. At the same time, it constitutes not only an ascending moral principle, a source of human rights and a value in law. In fact, human dignity is a basis for democratic rule of law, and its respect, as well as the high level of its protection is a key factor determining the legality of state. Unfortunately, the understanding of its meaning is mainly due to humiliation. However, it is not sufficient to consider human dignity only as an object of assault. It is more important to realize under what conditions human dignity will not be devalued.

During the war, the issue of respect and protection of human dignity is particularly acute. However, international legal instruments in the field of humanitarian law and human rights have the same approach - human dignity is an absolute value and cannot be devalued even in an armed conflict. In this case, states are required to ensure respect for human dignity, in particular through the creation of mechanisms and instruments which allow individuals the most affected by conflict feel themselves worthy and dignified. Based on the above, the level of protection of human dignity in armed conflict should be much higher, and the state cannot be released from the relevant obligation. In the context of compensation for damaged or destroyed property, this issue is relevant because it comes to daily practical implementation of human dignity of the victims of armed conflict, particularly internally displaced persons. The UN and Council of Europe legal acts clearly state the right of such persons to restitution and compensation, as well as the requirements for States to establish national mechanisms for compensation for damage caused by war. The deeper meaning of these actions of State is just an expression of respect for the war-affected people. It is also important to draw attention to the fact that the right to restitution and compensation is recognized as a way of restoring human dignity and justice of victims, as well as an integral element of the rule of law principle. 